\title{
Do Sri Lankan meals help decrease blood glucose response?
}

\author{
U P K Hettiaratchi' ${ }^{1}$, S Ekanayake ${ }^{1}$ and J Welihinda ${ }^{2}$ \\ (Index words: glycaemic index, glycaemic response, rice, fibre)
}

\begin{abstract}
Objective The prevalence of diabetes mellitus (DM) has rapidly increased in Asian countries including Sri Lanka during the past decade. Scientific data on postprandial glycaemic influence of common meals is essential when formulating diets. Objectives of this study were to analyse glycaemic indices (GI) of five common meals and effects of macronutrients, sources of carbohydrates, and physicochemical properties of starch on observed $\mathrm{Gl}$ values.
\end{abstract}

Design The meals analysed were; 1 - red rice (AT 353) meal, 2 - red rice mixed meal, 3 - stringhopper (wheat flour) meal, 4 - stringhopper (rice flour) meal, 5 - manioc (Manihot esculenta) meal.

Setting University of Sri Jayewardenepura.

Subjects Healthy individuals ( $n=10$; age: $20-30$ years).

Measurements $\mathrm{Gl}$ of each meal was calculated according to $\mathrm{FAO} / \mathrm{WHO}$ guidelines by taking the ratio of incremental area under blood glucose curve (IAUC) of test and the standard.

Results GI of meals $1-5$ were $99 \pm 10,60 \pm 5,104 \pm 7$, $102 \pm 11$ and $120 \pm 9$ respectively. The glycaemic response to rice mixed meal was significantly lower $(p<0.05)$ than the others. The total dietary fibre content showed a significant negative correlation $(p=0.044)$ with the GI value while the protein showed a non-significant negative relationship $(p>0.05)$. Red rice had a combination of intact, swollen and disintegrated starch granules while string hoppers and manioc showed only the latter two types.

Conclusion The rice mixed meal has the lowest glycaemic index. Presence of dietary fibre and a legume reduces the glycaemic response. Cooking may change the glycaemic response of certain food.

\section{Introduction}

The prevalence of diabetes mellitus (DM) is increasing in the world and in Sri Lanka [1,2]. Diabetic patients undergo dietary manipulations and are advised to avoid foods which give rapid and high blood glucose responses. Therefore knowledge of the blood glucose raising potentials of commonly eaten meals is important to avoid excessive blood glucose response. Glycaemic index (GI) is useful as it ranks food items depending on the blood glucose response following a meal.
According to the GI values foods are categorised as low, medium and high [3]. Low GI diets are beneficial in both type 1 (IDDM) and type 2 diabetes mellitus (NIDDM) [4-8]. Therefore a WHO/FAO expert committee endorses the use of GI in planning diets for diabetics [9].

Although there are data on GI of some basic Sri Lankan foods [10] sufficient information is not available on mixed Sri Lankan meals. This study was designed to estimate the GI of some Sri Lankan meals and to analyse the effects of the macronutrients (protein, fat, fibre), sources of carbohydrates and processing (cooking) on starch granules of local foods on the observed GI values.

\section{Materials and methods Study sample}

Non-diabetic individuals $(\mathrm{n}=10$, age $=20-30$ years, $\mathrm{BMI}=23 \pm 4 \mathrm{~kg} / \mathrm{m}^{2}$ ) participated in the study. Informed written consent was obtained from the individuals before enrolling for the study. Approval for the study was obtained from the Ethical Committee, Faculty of Medical Sciences, University of Sri Jayewardenepura.

\section{Foods}

White sliced bread bought from reputed retail outlets was used as the standard food. Red rice (AT 353) was obtained from Rice Research Institute, Batalegoda, Sri Lanka. The food items were prepared according to standard Sri Lankan recipes (Table 1).

\section{Determination of glycaemic indices}

Each meal contained $50 \mathrm{~g}$ of available carbohydrate from the main starchy staple and the starchy curries (Table 1). GI values of the meals given in Table 1 were determined according to $\mathrm{FAO} / \mathrm{WHO}$ procedure [10].

\section{Estimation of chemical compositions of meals}

Contents of digestible starch, fat, dietary fibre, protein and amylase were estimated using methods described elsewhere [11-15].

\section{Microscopic study of starch granules}

Starch in raw flour and processed/cooked food items were examined $(\times 10 \times 400)$ under a light microscope after staining with $\mathrm{KI} / \mathrm{I}_{2}$ solution.

${ }^{1}$ Department of Biochemistry, Faculty of Medical Sciences, University of Sri Jayewardenepura, Sri Lanka and ${ }^{2}$ Department of Biochemistry and Molecular Biology, Faculty of Medicine, University of Colombo, Sri Lanka.

Correspondence: SE, e-mail <sagarikae@hotmail.com>. Received 7 August 2008 and accepted 10 January 2009. Competing interests: none declared. 
Table 1. Meals and the portion sizes

\begin{tabular}{|c|c|c|c|}
\hline Meal & Meal composition & Preparation method & Portion size \\
\hline Meal 1: & Red rice & $1: 2$ (rice:water) cooked in a rice cooker & $203 \mathrm{~g}$ \\
\hline Red rice meal & $\begin{array}{l}\text { Coconut gravy } \\
\text { '(Kirihodi)' }\end{array}$ & $\begin{array}{l}100 \mathrm{~g} / 25 \mathrm{ml} \text { of first extraction and } 125 \mathrm{ml} \\
\text { of second extraction }\end{array}$ & $30 \mathrm{ml}$ \\
\hline \multirow{5}{*}{$\begin{array}{l}\text { Meal 2: } \\
\text { Red rice } \\
\text { mixed meal }\end{array}$} & Red rice (AT 353) & Same as above & $176 \mathrm{~g}$ \\
\hline & Lentil curry & $\begin{array}{l}100 \mathrm{~g} / \text { boiled in } 200 \mathrm{ml} \text { water } / 50 \mathrm{ml} \\
\text { coconut milk }\end{array}$ & $75 \mathrm{~g}$ \\
\hline & 'Gotukola' salad & $100 \mathrm{~g}$ 'gotukola' $+50 \mathrm{~g}$ coconut scrapings & $25 \mathrm{~g}$ \\
\hline & Egg & Boiled & \\
\hline & 'Kirihodi' & Same as above & $30 \mathrm{ml}$ \\
\hline \multirow{4}{*}{$\begin{array}{l}\text { Meal 3: } \\
\text { Stringhopper meal } \\
\text { (wheat flour) }\end{array}$} & Stringhoppers & $500 \mathrm{~g} / 450 \mathrm{ml}$ water & $162 \mathrm{~g}$ \\
\hline & Coconut sambol & & $25 \mathrm{~g}$ \\
\hline & Egg & Same as above & \\
\hline & 'Kirihodi' & & $60 \mathrm{ml}$ \\
\hline
\end{tabular}

\section{Meal 4:}

Stringhopper meal (red rice flour)

$\begin{array}{ll}\text { Stringhopper meal } & \text { Stringhoppers } \\ \text { (red rice flour) } & \text { Coconut sambol } \\ & \text { Egg } \\ & \text { 'Kirihodi' }\end{array}$

$500 \mathrm{~g} / 500 \mathrm{ml}$ water

$163 \mathrm{~g}$

Meal 5:

Manioc meal

Manioc (boiled)

$200 \mathrm{~g} / 200 \mathrm{ml}$ water

$200 \mathrm{~g}$

Coconut sambol

Same as above

$25 \mathrm{~g}$

Food items were dried at $35-45^{\circ} \mathrm{C}$ and milled $(0.315 \mathrm{mM})$ using an analytical mill (IKA ${ }^{\circledR} \mathrm{A} 11$ basic, Brazil). Flour samples were stored at $-20{ }^{\circ} \mathrm{C}$.

Table 2. Incremental area under curve (IAUC) and GI values of the meals

\begin{tabular}{lcc}
\hline Meal & IAUC & GI \\
\hline Meal 1: (Red rice meal)(RRM) & $184 \pm 29$ & $99 \pm 10$ \\
Meal 2: (Red rice mixed meal) (RRMM) & $97 \pm 16$ & $60 \pm 5$ \\
Meal 3: (Stringhopper-wheat flour) (SHWF) & $168 \pm 15$ & $104 \pm 7$ \\
Meal 4: (Stringhopper-red rice flour) (SHRF) & $186 \pm 18 \pm 11$ \\
Meal 5: (Manioc) & $206 \pm 21$ & $120 \pm 9$ \\
\hline
\end{tabular}

$\mathrm{N}=10$; IAUC and GI (Mean $\pm \mathrm{SEM})$. 


\section{Statistical analysis}

The results were analysed using Students' t-test by Microsoft Excel and Minitab (version 14) at 95\% confidence interval.

\section{Results and discussion}

The GI values of the meals studied ranged from 60-120 (Table 2). The red rice (alone-RRM) elicited a GI value of $99 \pm 10$ and can be categorised as a high GI variety [3]. When the same rice variety was given as a mixed meal containing typical components of a Sri Lankan meal (RRMM), the GI declined by $39 \%$. The glycaemic response to RRMM is also significantly lower $(p<0.05)$ than the other meals studied. The rice mixed meal studied in the present study had the highest protein, IDF and total dietary fibre (TDF) contents among the meals studied. The increase of protein (59\%), fat (43\%) and TDF (29\%) might have contributed to the significant difference in GI between the RRM and RRMM.

The two stringhopper meals (made with rice-SHRF; wheat-SHWF) contained same fibre, fat sources with identical amounts but different protein sources (egg and the respective flours [wheat and rice]) and amounts (SHWF had 35\% more protein than SHRF). Despite the differences in flour and protein contents in the string hoppers, when given with the same curries the blood glucose responses were similar (i.e. GI not significantly different, $p=0.712$ ). This could be due to the extensive degradation of starch granules (Figure 2) during string hopper preparations thus making the starch readily available following ingestion.

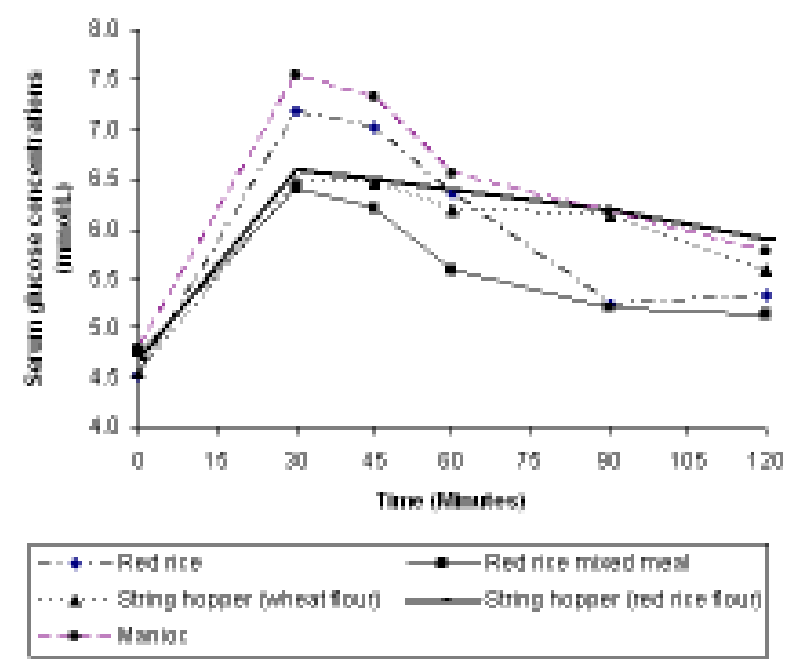

Figure 1. Blood glucose responses to the five test meals
SHRF had $37 \%$ protein, $67 \%$ fat and $17 \%$ TDF more when compared with RRM. Still SHRF had a higher GI (4\%) indicating a strong correlation of GI and the food preparation method. If the starch granules are extensively degraded (Figure 2) due to preparation (processing/ cooking) the inclusion of other macronutrients will not be effective in reducing GI. Thus the degree of gelatinisation plays a major role in influencing the glycaemic response of a food. Manioc being a tuber had a high blood glucose raising potential as other tubers (i.e. potato - 70-130; sweet potato-63-111) and the highest GI [17].

The effect of the macronutrients of the meals on GI were analysed and a significant negative correlation ( $\mathrm{p}=$ 0.044 ) was seen with TDF content (Figure 3). Protein, IDF and SDF contents showed non-significant $(p>0.05)$ negative relationships. The fat [4], TDF and phytate [18] have been shown to influence the glycaemic response of foods. The diets high in carbohydrate and fibre and low in fat are reported to be beneficial in improving carbohydrate metabolism in individuals with diabetes [19].

The two string hopper varieties (Figure 2-c, 2-e) and manioc (boiled) had highly swollen and disintegrated granules (Figure 2-g) when observed under a light microscope. Red rice (cooked) contained some intact granules with highly swollen and disintegrated granules (Figure 2-b). The cooked lentils contained highly swollen intact granules or cell enclosed granules making them less susceptible to the action of the digestive enzymes (Figure 2-i).

The sources of carbohydrates influence plasma glucose and insulin responses [20-21]. RRMM contained two carbohydrate sources; rice (cereal) and lentils (legumes). This might have also led the GI of the RRMM to decline as legume starch show a slow and prolonged glycaemic response following ingestion. The incorporation of legumes reduce the postprandial level in diabetics [22]. This is important in the long term glycaemic control of diabetics as rapidly absorbed carbohydrates stimulate a considerable increase in serum insulin which is followed by a rapid decrease in blood glucose [23, 24]. The decrease in blood glucose may in turn stimulate counter regulatory hormones and free fatty acid release, which may be associated with insulin resistance and impaired carbohydrate tolerance [24] .

Amylose content of the starchy food items vary from 24-45 g/100 g starch. The relationship between the GI of rice varieties and amylose is exponential rather than linear [16]. The rice variety we analysed had 35\% (or $35 \mathrm{~g} / 100 \mathrm{~g}$ starch) amylose content but still a high GI of $99 \pm 10$. This might be partly due to the presence of swollen or disintegrated starch granules in the cooked rice (Figure 2-i). Different varieties of rice of similar amylose content give different glycaemic responses and this has been attributed to the other physicochemical properties of starch [25]. 


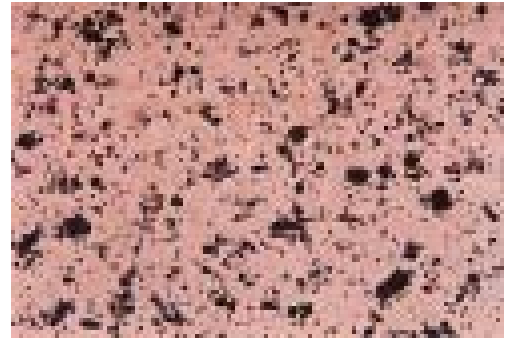

(a)

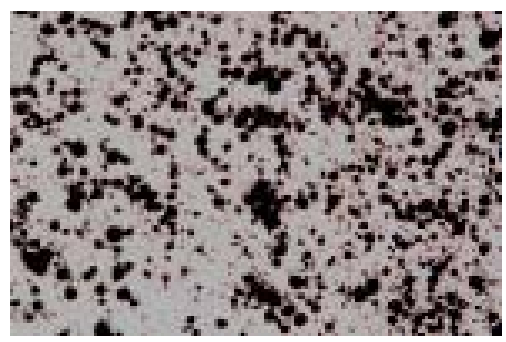

(d)

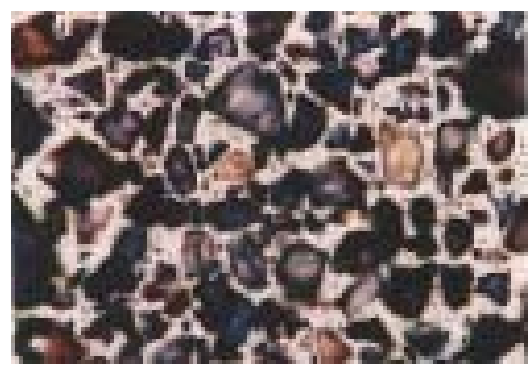

(g)

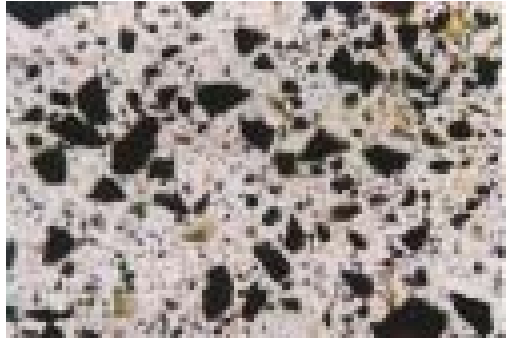

(b)

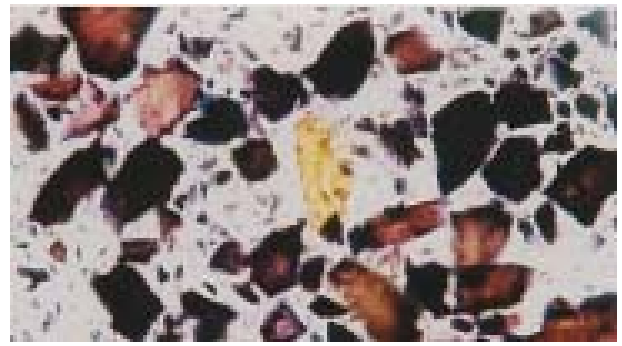

(c)

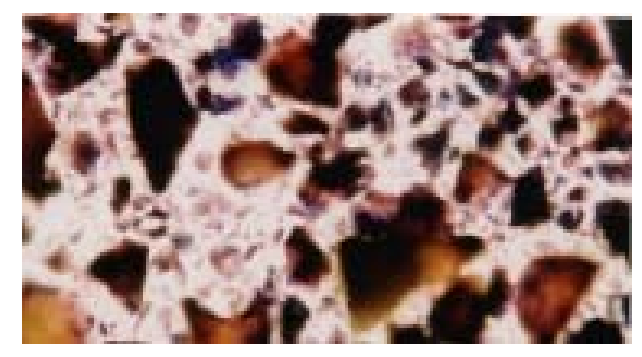

(e)

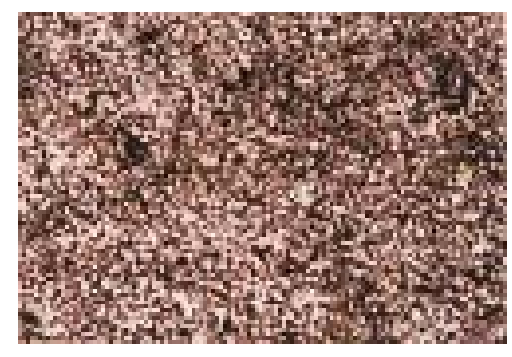

(f)

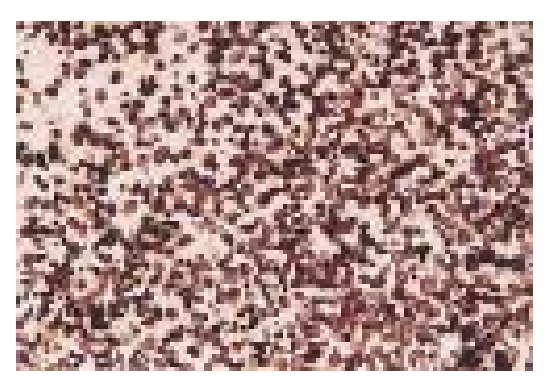

(h)

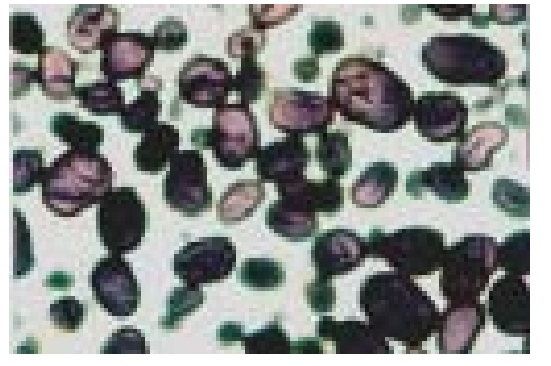

(i)

Figure 2. Microscopic examination of starch granules a-Red rice flour (raw); b-Red rice (cooked); c-String hopper (red rice flour); $\mathbf{d}$ - Wheat flour (raw); e - Stringhopper (wheat flour); f - Manioc flour (raw); g - Manioc (boiled); h - Lentils (raw); i - Lentils (cooked - cell enclosed starch granules).

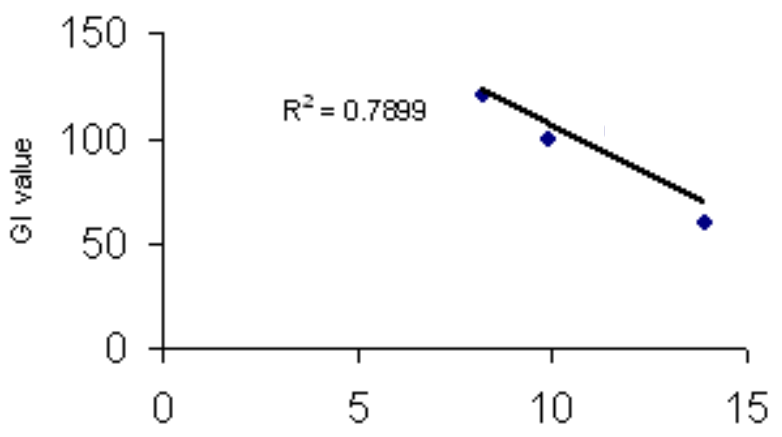

Total Dietary Fibre ( $\mathrm{g} / 50 \mathrm{~g}$ available carbohydrate portion)

Figure 3. Effect of total dietary fibre [TDF $(\mathrm{g} / 50 \mathrm{~g}$ available carbohydrate portion)] of the meals on glycaemic index values.

\section{Conclusion}

The GI values of the five meals analysed ranged from 60-120. The rice mixed meal had the lowest GI. The glycaemic response of the meals showed a significant negative correlation with the dietary fibre content. Inclusion of a legume in the rice mixed meal decreases the glycaemic response while maintaining the palatability.

\section{Acknowledgement}

The authors acknowledge the financial assistance given by the grants; National Science Foundation $\mathrm{NSF} / \mathrm{RG} / 2005 / \mathrm{AG} / 10$, International Foundation of Science, Sweden; E-3941/1 and National Research Council NRC-05-03. 


\section{References}

1. King H, Aubert RE, Herman WH. Global burden of diabetes. Diabetes Care 1998; 21: 1414-31.

2. Weekly Epidemiological Report, Sri Lanka. Aglobal pandemic: diabetes in Indo-Asians; 2004 August. Report No: 87.

3. Beals KA. The glycaemic index: research meets reality. 2005. Special publication of Potato Board, USA.

4. Jenkins DJA, Wolever TMS, Taylor RH, Barker H, Fielden SRDH, Baldwin JM, et al. Glycaemic index of foods: a physiological basis for carbohydrate exchange. American Journal of Clinical Nutrition 1981; 34: 362-6.

5. Jarvi AE, Granfeldt YE, Bjorck IE, Asp NG, Vessby BOH. Improved glycaemic control and lipid profile, and normalised fibrinolytic activity on a low glycaemic index diet in type 2 diabetic patients. Diabetes Care 1999; 22: 10-8.

6. Frost G, Beecham J. Dietary advice based on the glycaemic index improves dietary profile and metabolic control in type 2 diabetic patients. Diabetic Medicine 1994; 11: 397-401.

7. Wolever TMS, Vuksan V, Jenkins AL, Wong GS, Josse RG. Beneficial effect of low glycaemic index diets in overweight NIDDM subjects. Diabetes Care 1992; 15: 562-4.

8. Bornet FRJ, Costagliola D, Rizkalls SW, Blayo A, FontvieilleA, Haardt $\mathrm{M}$, et al. Insulinaemic and glycaemic indices of six starch-rich foods taken alone and in a mixed meal by type 2 diabetics. American Journal of Clinical Nutrition 1987; 45: 588-95.

9. FAO/WHO. Carbohydrates in human nutrition: report of a joint FAO/WHO expert consultation; 1998.

10. Hettiarachchi P, Jiffry MTM, Jansz ER, Wickramasinghe AR, Fernando DJS. Glycaemic indices of different varieties of rice grown in Sri Lanka. Ceylon Medical Journal 2001; 46: $11-4$.

11. Holm J, Drews A, Asp NG. A rapid method for the analysis of starch. Starch/Starke 1986; 38: 224-6.

12. Croon LB. Setthaltsbestamning I mgol och mjolprodketer. (Crude fat analysis of different flours and flour products). Var Foda 1980; 32: 425-7.

13. Asp NG, Hallmer H, Siljestrom M. Rapid enzymatic assay of insoluble and soluble dietary fibre. Journal of Agriculture and Food Chemistry 1983; 31: 476-8.

14. Association of Official Analytical Chemist. Official methods of analysis of the AOAC, 14th ed. AOAC, Washington, DC, 1984; 14. 06.

15. Mohammadkhani A, Ttoddard FL, Marshall DR, Uddin MN, Zhao X. Starch extraction and amylose analysis from half seeds. Starch/Starke 1990; 51: 562-6.

16. Brand-Miller J, Pang E, Bramall L. Rice: a high or low glycaemic index food? American Journal of Clinical Nutrition 1992; 56:1034-6.

17. Foster-Powell K, Holt SH, Brand-Miller JC. International table of glycaemic index and glycaemic load values: 2002 . American Journal of Clinical Nutrition 2002; 76: 55-6.

18. Trout D, Behall K, Osilesi O. Prediction of glycaemic index for starchy foods. American Journal of Clinical Nutrition 1993; 58: 873-8.

19. Jenkins DJA, Buckley G, Lam KY, Giudici S, Kalmusky J, Jenkins AL, et al. Low glycaemic index starchy foods in the diabetic diet. American Journal of Clinical Nutrition 1988; 48: $248-54$.

20. Coulston AM, Greenfield MS, Kraemer FB, Tobey TA, Reaven GM. Effect of differences in source of dietary carbohydrate on plasma glucose and insulin responses to meals in patients with impaired carbohydrate tolerance. American Journal of Clinical Nutrition 1981; 34: 2716-20.

21. Crapo PA, Kolterman OG, Waldeck N, Reaven GM, Olefsky MD. Postprandial hormonal responses to different types of complex carbohydrates in individuals with impaired glucose tolerance. American Journal of Clinical Nutrition 1980; 33: 1723-8.

22. Chew I, Brand J, Thorburn A, Truswell A. Application of glycaemic index to mixed meals. American Journal of Clinical Nutrition 1988; 47: 53-6.

23. Jenkins DJA, Taylor RH, Griffiths C, Krzeminska K, Lawrie JA, Bennet CM, et al. Slow release dietary carbohydrate improves second meal tolerance. American Journal of Clinical Nutrition 1982; 35: 1339-46.

24. Wolever TMS, Ocana AM, Rao VA, Collier GR. Second meal effect: low glycaemic index foods eaten at dinner improve subsequent breakfast glycaemic response. American Journal of Clinical Nutrition 1988; 48: 1041-7.

25. Panlasigui L, Thompson L, Juliano B, Perez C, Yiu S, Greenberg G. Rice varieties with similar amylose content differ in starch digestibility and glycaemic response in humans. American Journal of Clinical Nutrition 1991; 54: 871-7. 


\title{
Microbiological quality of well water in Kalutara District
}

\author{
S Kushlani Jayatilleke ${ }^{1}$ and S Shyamalee V Gunawardana ${ }^{1}$ \\ (Index words: water quality, microbiology, Escherichia coli, well water)
}

\begin{abstract}
Objective To investigate the microbiological quality of well water in the Kalutara district.

Method A retrospective analysis was carried out of reports on water samples taken from tube wells, protected wells and unprotected wells in Kalutara district in 2007. Information was obtained from laboratory registers and request forms.
\end{abstract}

Results In 2007, the microbiological quality of 185 samples of well water had been tested. Of these, 120 $(64.86 \%)$ were unsuitable for consumption, and 106 $(57.3 \%)$ samples were contaminated with Escherichia coli.

Conclusions A high percentage of well water samples tested from the Kalutara District were unsuitable for consumption, with over half contaminated with Escherichia coli.

\section{Introduction}

The year 2008 was declared as International Year of Sanitation by the World Health Organisation (WHO). Provision of an adequate supply of safe drinking water is one of the main aims of proper sanitation. On average, as much as one-tenth of a person's productive time is wasted due to disease resulting from consumption of contaminated water. About $77 \%$ of the population of Kalutara district in Sri Lanka, use well water as their main source of drinking water [1]. According to the WHO, non-pipe borne water supplies, including water from wells or springs, may often be contaminated with pathogens [2]. Water from such sources often requires treatment and protected storage in order to be safe for consumption [2].

There are very few published studies on microbiological quality of well water in Sri Lanka [3]. A study in the Kurunegala district in 1987-1988 [4], found that 60\% of people used protected wells, 30\% used unprotected water sources, and $10 \%$ used hand pumps and piped water supplies. In this study the proportion of contaminated samples was high, with the exception of piped supplies and water from hand pumps. The faecal coliform count was highest in water from unprotected sources [4].

This study was undertaken to evaluate microbial contamination of well water in the Kalutara district.

\section{Methods}

A retrospective analysis of laboratory data on water samples taken from tube wells, protected wells and unprotected wells in the Kalutara district was carried out. Information was obtained from laboratory registers and request forms, and analysed manually.

Water samples, which were collected following a standard procedure in sterile bottles were brought to the laboratory within 2 hours of collection or in ice packs if later by Public Health Inspectors trained in the collection and transport of water samples. Presumptive coliform counts and $E$. coli counts were determined using the multiple tube method. On the first day $10 \mathrm{ml}$ and $1 \mathrm{ml}$ of each sample were inoculated into 5 tubes of double strength and 5 tubes of single strength MacConkey Broth, respectively. $1 \mathrm{ml}$ of a 1 in 10 dilution of each sample was also added to 5 tubes of single strength MacConkey Broth. Tubes were incubated for 24 to 48 hours at $37^{\circ} \mathrm{C}$, and observed for gas and turbidity. The number of tubes positive for gas and turbidity for each sample were read according to the MPN table and presented as the total coliform count per $100 \mathrm{ml}$. The positive tubes were then sub-cultured to Brilliant Green Bile Broth and Tryptone Water, and incubated at $44^{\circ} \mathrm{C}$ for 24 to 48 hours. Kovac's reagent was added to the Tryptone Water tubes and mixed. Appearance of a red ring at the upper layer indicates a positive indole test. The number of tubes with production of gas at $44^{\circ} \mathrm{C}$ and a positive indole test was taken as being positive for $E$. coli, and the count was read according to the MPN table. The results were interpreted by a Consultant Microbiologist using the Sri Lanka Standard 614: Part 2:1983 with amendments approved in 1988 [6].

\section{Results}

The microbiological quality of 185 samples of well water from the Kalutara district was tested in 2007. Of these, $120(64.86 \%)$ were unsuitable for consumption, and $106(57.3 \%)$ were contaminated with E. coli, indicating recent faecal pollution.

\section{Discussion}

The WHO recommended indicator organism of choice for faecal pollution is E. coli. Water intended for

${ }^{1}$ National Institute of Health Sciences, Kalutara, Sri Lanka.

Correspondence: SKJ, e-mail <kush_jaya@yahoo.co.uk>. Received 26 July 2008 and revised version accepted 27 February 2009. Competing interests: none declared. 
human consumption should not contain E. coli [5]. We found that nearly two thirds of water samples from wells in the Kalutara district were microbiologically unsuitable for human consumption. A survey undertaken by the Department of Census and Statistics in Sri Lanka in 2006 to 2007 concluded that $86 \%$ of households in Sri Lanka use safe drinking water [3]. This was on the assumption that water from protected wells, and tube wells and pipeborne water is safe. However, protected wells may have microbial contamination even though they are protected at the ground level. A survey done in tsunami affected areas of the Southern Province of Sri Lanka showed that $80 \%$ of people were satisfied with the provision and quality of drinking water [6]. However, a study carried out in the Matara district using a field test kit for $\mathrm{H}_{2} \mathrm{~S}$ has shown that water obtained from $65 \%$ of dug-up wells and $100 \%$ of tube wells has faecal contamination [7]. This data is comparable to ours, although we could not obtain information of the type of wells from which our water samples were obtained.

There is no planned protocol for sampling of well water for microbiological analysis in Sri Lanka. Though there is an understanding that water samples from the Kalutara district should be sent to the Laboratory of National Institute of Health Sciences for microbiological testing, there is no proper mechanism to monitor it.

\section{Conclusion}

Most well water samples tested from the Kalutara district were unsuitable for human consumption. The community should be educated regarding the high possibility of contamination of well water and the importance of boiling or otherwise treating water before consumption.

\section{References}

1. Department of Census and Statistics. Census of population and housing 2001, Sri Lanka: Kalutara district report, 2004, 723 .

2. WHO. Guidelines for drinking water quality. www.who.int. 122-144c.

3. Department of Census and Statistics. Household Income and Expenditure Survey 2006/2007, 53.

4. Mertens TE, Fernando MA, Marshall TF, Kirkwood BR, Cairncross S, RadalowiczA. Determinants of water quality, availability and use in Kurunegala, Sri Lanka. Annals of Tropical Medicine and Parasitology 1990; 41: 89-97.

5. Bureau of Sri Lanka Standards. Specification for potable water, part 2: bacteriological requirements. SLS 614, part 2, 1983 (with amendments approved in 1988).

6. Wickramasinghe WA, Widanapathirana ND, Vijayabandara GD, Karunathilake IM. Are tsunami survivors satisfied with the provision and quality of healthcare they received? Asia Pacific Journal of Public Health 2007; 19: 35-9.

7. Rathnayake TL, Rathnyake RMUK. How safe is our drinking water? Journal of the Ruhunu Clinical Society 2008; 15: 17-9. 